\title{
VIRTUAL REALITY SYSTEM FOR JOB INTERVIEW APPLICATION: A DEVELOPMENT RESEARCH
}

\author{
Moh.KholilurrahmanJailani. ${ }^{1}$, LaelaHikmahNurbatra ${ }^{*}$ \\ English Language Education Department, University of Muhammadiyah Malang- Indonesia ${ }^{1}$; \\ English Language Education Department, University of Muhammadiyah Malang-Indonesia ${ }^{2}$ \\ mkholilurrahmanj@gmail.com; nurbatra@umm.ac.id \\ *: corresponding author
}

\begin{abstract}
Technology has become more sophisticated and widely used in pedagogical process. One of sophisticated technologies that is recently known and became attractive towards the public attention is Virtual Reality. This system applied simulated object and artificial environment like the real-world version. A need analysis conducted by Jailani (2017)on the use of VR for Business English students indicated that the students were interested and enthusiastic to learn job interview.The objective in the current research is to develop Virtual Reality System for Job Interview in Business English class at University of Muhammadiyah Malang. In doing so, the present research applied seven procedures in Research and Development design which aimed to develop some features and contents that are applied on Job Interview application. The subjects of this research are students from Business English (BE) class, English Language Education Department of UMM academic year 2016/2017. Observation, questionnaire, and documentation were employed to collect the data. The data were then transcribed and analyzed to reach the research purpose.The result revealed that the application is in very valid category that reached 93.33\% for product and design validation; while $93.75 \%$ for content validation. Moreover, additional features were developed on stuffs, scoring system, and button to make the users more interested in using VR. In addition, it was found that the students of Business English as users were motivated and attracted in conducting job interview simulation through Virtual Reality.
\end{abstract}

Keywords: Job Interview application, Virtual Reality, Business English students.

\section{INTRODUCTION}

To a large degree, the notion of technology becomes significantly urging on the aspect of utilizing people to help their activities in their daily life nowadays. It is known that technology is always updated rapidly in every single space of human needs. Motteram (2013) stated that technology continues to be used for all sorts of specific language learning activities, such as the development of speaking, writing, and reading. In line with this, the use of smarthphone as one of media in develompment of technology has emerged in education for learning. Learning activities with smartphones, facilitate and attract students to learn, so that their perspective extended (Rambitan, 2015). In line with that idea, Clayton \& Murphy (2016) reported that students use smartphone or mobile phone in the percentage of $88 \%$ nowadays in overall. 
One of the sophisticated technologies that uses smartphone to run the system is Virtual Reality System. This term came to the public's attention in the late 1980's and 1990's that may be manipulated and moved through by a user in real time in describing a computer-generated virtual environment (Mandal, 2013). It relates with simulated objects in that environment or situation like the real-world vision. This technology becomes well-known and fashionable in current decade because of the idea of life view when user used it and interacted with Synthetic environment. Synthetic Environment is used to describe computer-mediated human interaction with the simulated environment which also includes physical reaction (Draper et al., 1999, as cited in Ma \& Kaber, 2006).

Since Palmer Luckey created Oculus Rift to make Virtual Reality System working inside the software connected with the glasses in March of 2014, it becomes popular in the field of new technology expanded (Clark, 2014). Recently, Virtual Reality (VR) known for having game simulation like the VR product from Palmer Luckey applied, users can use it like they are in the real-life situation. The development of Virtual Reality System in educational environment emerges in huge interaction such as educational games and Virtual Reality as Disruptive Technologies (Psotka, 2013), Virtual Reality in teaching environmental engineering (Burnley, 2017), Virtual Reality for learning style and teaching learning process (Gutiérrez, Mora, Diaz, \& Marrero, 2017), Virtual Reality in medicine (Gutiérrez et al., 2017), Virtual Reality Engineering Education (Abulrub, Attridge, \& Williams, 2011), Virtual Reality in Biology Education (Shim et al, 2010).

A recent study on pointing Virtual Reality for an incredible future technology besides implementing on game simulation has already been done by some experts. Wilson, Soranzo, \& Sheffield (2015) concluded that the use of VR in psychological study has increased because its benefits afforded over traditional experimental apparatus in the possibility of creating more ecologically valid stimulus presentation and response protocols and more strict control of the environment. In healthcare field, students can directly examine and interact with virtual patient as well as learn sill like in a real world so that they can surgery and even perform procedures on a virtual patient in safe and controlled environment, and this system has wide applications ranging from diagnosis, counselling, treatment, and rehabilitation, to designing of hospitals (Chaudhury, 2014). The other way of developing Virtual Reality System on educational fields would involve the students of Business English in terms of practicing job interview before they apply for job.

Business English subject is part of English for Specific Purposes as a distinct field from General English (Bereczky \& Gabor, 2009).Kučírková, Vogeltanzová, \& Jarkovská (2011) stated that Business English course concerns on the use of knowledge in business and management sphere, in negotiations with foreign partners, in the sphere of research etc. One of the courses in Business English that deals with the preparation of 
job fields is Job Interview. Job Interview is the current issue that author takes away from the needs of students that they plan to have a job after they have graduated. Job Interviews Guide (2011) identified what the candidate of employees are looking for, know what you can offer them, prepare yourself well and promote yourself as the best match to their needs. This is the effort of the author to attain the aim of VR function on educational term to make the learners more enjoyable in learning and increase the speaking skill by using media supported device.

Regarding that field of study, the researcher develops Virtual Reality in educational environment, by focusing on the implementation of Virtual Reality System on Business English students. Business English (BE) in the University of Muhammadiyah Malang (UMM) is an elective course at English Language Education Department (ELED) Faculty of Teacher Training and Education. This study learns about the matters found in business place. In the early level, it talks about how to write a systematic and good Business letter as its tool to interact or to make a convention with the others.

Needs analysis media in Job Interviews presented that the use of Virtual Reality System on VR Glasses is needed to be developed for students of Business English UMM in practicing job interview before they face the real environment of interview (Jailani, 2017). Students thought that the early existance of Virtual Reality technology facilitates them in interesting and fun learning on educational fields because they only know about the concept of interview without getting a chance to directly train themselves in the interview simulation. Hence, VR Glasses with the use of software inside smartphone should be developed in terms of the features and additional questions in order to make the students more practice especially in speaking activity.

In this research, the author will develop a Virtual Reality System on media to increase students' speaking ability and prepare them for practicing job interview which is used in software application of Job Interview Simulation by VR Glasses. The author will conduct Research and Development Program with the title "Developing Software of Job Interview Application on Virtual Reality System Using VR Glasses for Business English Students". Therefore, the research of the problem is focused on how Virtual Reality System can develop the software of Job Interview Application using VR Glasses.

\section{METHOD}

\section{Research Design}

This research uses Research and Development design which can be interpreted as the use of research method for researching, producing, and examining a new product so that it can be developed according to the needs (Sugiyono, 2011). Additionally, Sukmadinata (2013, as cited in Novitasari, 2016) stated that this kind of research method is the step or process to develop a new product or complete design of the 
existing product that can be accounted. Moreover, Borg and Gall (2003, as cited in Walisongo, 1983)supported that the process of $\mathrm{R} \& \mathrm{D}$ studying research finding that will be developed, developing the product, field testing, and revising the product.

The Research and Development design will be used by the researcher to develop the software of job interview application by using Virtual Reality System. This research focuses on the development of design, content, and features of the job interview software. The aim of the Virtual Reality application development is to develop materials that will be applied in the VR application in the context of job interview.

\section{Research Subject}

The subjects of this research are 10 students from 65 students that already knew about the technology of virtual reality before. The students are from business English (BE) class English Language Education Department at one of Universities in Malang, East Java academic year 2016/2017. The selected subjects have studied Business English as the one of the elective courses in English Language Education Department; this course also gives a chance to the students to do the apprenticeship program. An apprenticeship program gives a chance to the students in entering the workforce to combine on-the-job training with academic instruction that they learned before. This apprenticeship helps students implement their academic skills toward practical use in various work-fields.

\section{Model and Procedure of Development}

Research and Development approach by adapting Sugiyono's Model is conducted. Sugiyono (2011) describes the ten steps of research and development implementation strategy as follows:

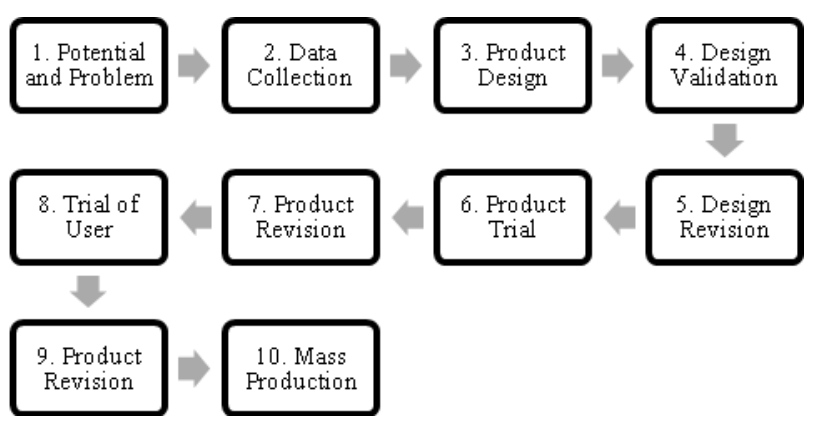

Figure 1. Steps of Research and Development

However, the current research modifies the steps into 7 procedures. The procedure of Research and Development in developing job interview application on Virtual Reality System for Business English students is explained as follow: 


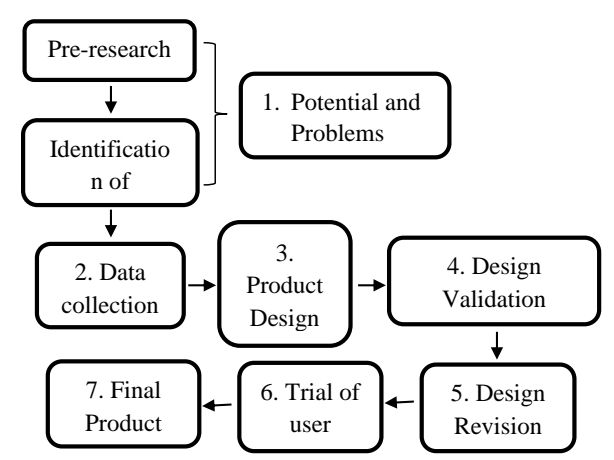

Figure 2. Procedure of Research and Development

\section{Potential and Problems}

Pre-Research is conducted by the researcher on students of Business English Class. It aims to identify the potential and problems on having a good interview and getting information to design the purpose of the study. The researcher analyses some aspects, which are curriculum, teaching materials, and teaching media.

\section{Data Collection}

Once the potentials and problems can be demonstrated factually and up to date, further information needs to be gathered as material for specific product planning that is expected to address the problem. Collecting the data is also designing the use of Virtual Reality System to apply the application of job interview.

\section{Product Design}

The products that produced in Research and Development research is the media of learning by using Virtual Reality Glasses in the field of technology. The used of application to apply on that related media was designed on the system of Virtual Reality with the real situation of job interview session. This product will be developed on the features and job interview question that needed by the interviewee.

\section{Design Validation}

Design validation is the process involving someone who have been expert to assess and evaluate the product design. This validation proposes to optimize the work of application before trial. There are two experts who will validate this product. The first expert focuses on validating the use of technology on application. This expert currently works at the Department of Informatics Engineering and has Master Degree of Science. He ever did research in information Science, Algorithms and Artificial Intelligence. His current project is 'Indonesian Twitter NLP' and 'Indexing for multi-feature data'. His skills and expertise are in Feature Extraction, Image Segmentation, Information Retrieval, Image Retrieval, and Abstracting and Indexing as Topic. He also ever became Head of Informatics and Engineering Department. The second expert focuses on validating the content of application related to the job interview. The second expert is the lecturer of Business English. This expert is senior lecturer in English Language 
Education Department and the Director of Kursus Bahasa Asing (KBA) which has doctoral degree and qualified in recruiting staff and doing interview for the job in her office.

\section{Design Revision}

After the expert validated the design of the product, the researcher develops the product by doing some revision about the design. This term can be concerned to the comments, suggestion, or even evaluated items in the rubric of validation.

\section{Trial of user}

After testing the product successfully, then the next product that has been revised by expert applied new additional aspects on application. The users will try the product with the need analysis before. Therefore, the researcher used data collection which is the most strategic step in the research because the main purpose of the research is to get data. Data collection conducted in this study is as follows:

\section{- Observation}

In this study, the researcher used observation in order to collect information and get descriptive condition to provide answers on how Business English students learned about interview in learning process. The activity can be related to the way teacher teaches, student learns, media uses, and etc. Additionally, this observation aimed to not only observing the subject but also knowing about the existing of Virtual Reality System that can be used for media in learning interview by the students in facing jobmarket process.

In line with this, this study uses participant observation when the researcher is involved in learning process of Business English class with the other students. Therefore, this kind of observation can be easily analyzed by the researcher to get description and some related problems in interview session.

- Questionnaire

The author gives a list of questions (questionnaires) that must be filled and submitted. The type of questionnaire used is closed which is a set of questionnaires with possible answers available, where respondents only choose one of the possible answers. To complete the answer, this kind of questionnaire applied multiple choice that have to be filled by the respondents.

In this study, questionnaires areequipped to obtain the expert' validation and users' validation. The questionnaires which are given to the expert have the aim to assess and test the validity of the product of job interview application. The expert will give score, comments, and suggestions in terms of three criteria of validation, namely Product Validation, Design Validation, and Content Validation. Product and Design validation need to be evaluated with the expert regarding on the appropriate technology that applied on the Virtual Reality System. Meanwhile, for content validation, the expert 
will concern on the material of job interview that has been implemented in the form of questions for student's practice.

The questionnaires for the users have the purpose to know the users' feedback about the use of media after they tried it. The users which are the students of Business English Class in English Language Education Department will give their score, comments, and suggestions in terms of three criteria, namely Product, Content, and Design. The proposed of statements in users' validation questionnaire address to decide the application of the product. Therefore, these questionnaires were used to find out the respond about job interview application that developed using Virtual Reality System.

\section{- Documentation}

Documentation process was used to get the data concerning on developing the design for job interview application. The document analysis that used by the researcher is the lecturer's material in the form of slide presentation about job interview that have been delivered to the Business English students. This method was proposed as the evidence developing the media to the Business English students that is through analyzing document that have been taken at the moment when the author observed the learning process (Sukmadinata, 2016). The documentation focuses on related job interview questions that will use as consideration in developing content material in job interview application.

\section{Final Product}

Making this final product will be done if the product has been tested effectively and ready to use. It concerned about the result of expert validation and the user's trial. The final product hopefully can be applied on regular practice for the students if they need to train themselves in interview session. This final product also will be able to be used in different context for university students who need to practice for job interview.

\section{Data Analysis}

The researcher analyzed the data from observation and questionnaire session based on procedures in order to answer the research problems. The procedures of analyzing data are described as follows:

1. Analyzing lecturer's material in the form of slide presentation about job interview to review about the use of question for job interview application.

2. Classifying the data from observation to develop the job interview application design in order to make it appropriate based on the needs of Business English student to practice with the question of interview.

3. Classifying the data from the experts' questionnaire regarding on the validation of technology and content. 
4. Analyzing the data from first experts regarding on technology validation in the form of product and design validation.

5. Analyzing the data from second experts regarding on content validation in the form of the appropriate material for job interview questions.

6. Analyzing the score of experts' validations by the formula below.

$$
\text { Nilai }=\frac{\text { The number of validation scores obtained }}{\text { The maximum number of validation scores }} \times 100 \%
$$

The result of data percentage was converted based on the criteria in table 1 below.

\begin{tabular}{ccl}
\hline No & \multicolumn{1}{c}{ Validity Criteria } & \multicolumn{1}{c}{ Validity Level } \\
\hline $\mathbf{1}$ & $85.01 \%-100.00 \%$ & $\begin{array}{l}\text { Very Valid, or it can be } \\
\text { used without revision }\end{array}$ \\
\hline $\mathbf{2}$ & $70.01 \%-85.00 \%$ & $\begin{array}{l}\text { Quite Valid, or it can be } \\
\text { used but needs minor } \\
\text { revision }\end{array}$ \\
\hline $\mathbf{3}$ & $50.01 \%-70.00 \%$ & $\begin{array}{l}\text { Less Valid, it is } \\
\text { recommended not to be } \\
\text { used because of major } \\
\text { revisions }\end{array}$ \\
\hline $\mathbf{4}$ & $01.0 \%-50.00 \%$ & $\begin{array}{l}\text { Invalid, or it may not be } \\
\text { used }\end{array}$ \\
& &
\end{tabular}

Source: Akbar, 2013

Table 1 is Validity Criteria and Validity Level of the Product

7. Analyzing the data from users' questionnaire to find out the response of students after trying to use the media.

8. The researcher draws the conclusion based on data analysis.

\section{FINDINGS AND DISCUSSIONS}

\section{Findings}

The researcher presents the findings of the study which include application validity, trial of users, and product design.

\section{- Application Validity}

In order to ensure that the application of Virtual Reality is ready to use for practicing job interview by the students, validation was needed and conducted by the researcher toward two experts. The first expert focused on the validation of product and design in the implementation of job interview on Virtual Reality. The second expert concerned to the three types of rubric, namely rubric for interviewee, interviewer, and interview content. The application validity by the validator was done before the application try out toward the students. The first validation about the product and the design of the application was done by the expert from Informatics Engineering Department with the following result: 


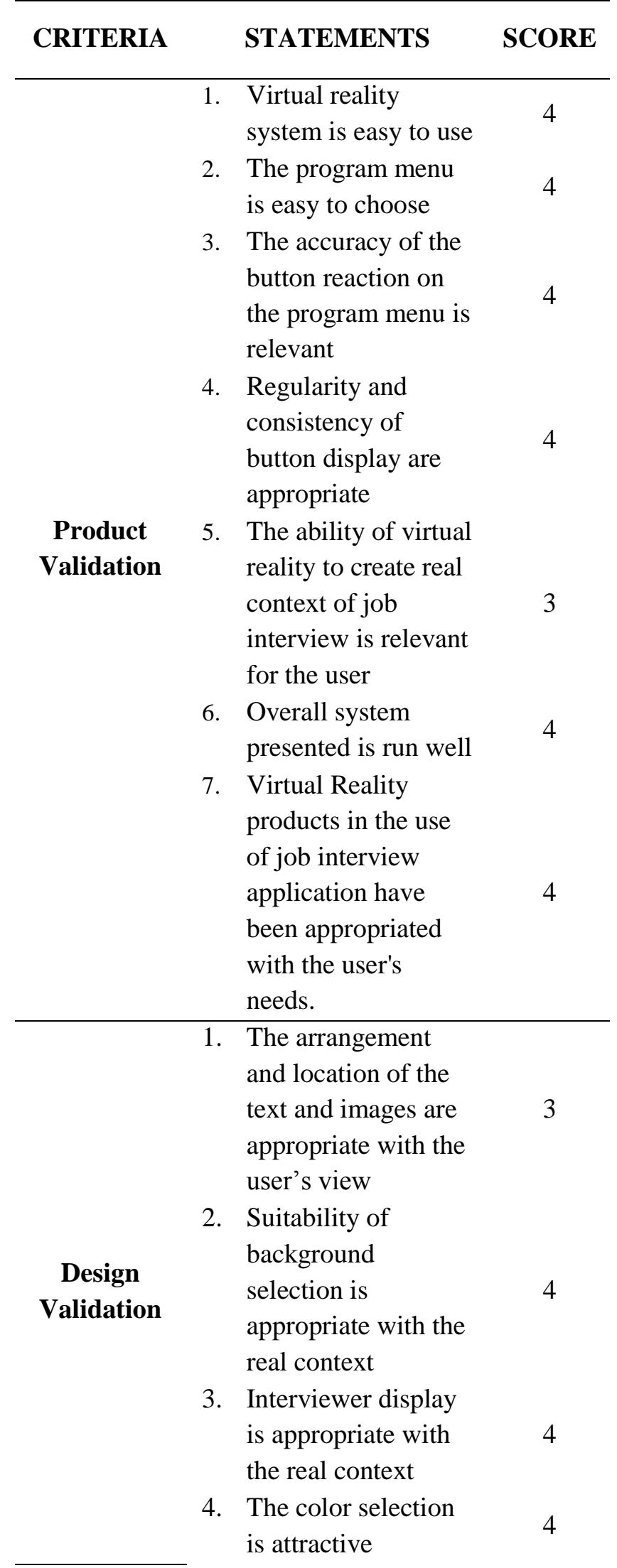


5. The selection of font and type are appropriate with the 4 user's view

6. The environment presented is appropriate with the real context

7. The environment presented is attractive

8. Virtual reality display for job interview is suggested for the user who want to know the real context of interview session

\begin{tabular}{cc}
\hline Total & $\mathbf{5 6}$ \\
\hline Validation Score & $\mathbf{9 3 . 3 3 \%}$ \\
\hline
\end{tabular}

Table 2 is The Result of Product and Design Validation on the Implementation of Job Interview on Virtual Reality

The Application of Job Interview in terms of the system was validated based on the assessment of two aspects, namely: (a) product validation and (b) design validation. According to the validation by the expert, the score of the product and the design validation reach $93.33 \%$ which was obtained from the calculation of the scores of statements in the rubric.

The next validation is about the content which focused on the interviewee, interviewer, and the interview question. It was done by the expert from English Language Education Department who teaches the elective course of Business English subject. The expert is familiar to the recruitment of employee and interview session. So that the rubric is more detail on the content of the application with the following result:

\begin{tabular}{|c|c|c|}
\hline CRITERIA & STATEMENTS & SCORE \\
\hline \multirow{2}{*}{$\begin{array}{l}\text { Rubric for } \\
\text { Interviewee }\end{array}$} & $\begin{array}{l}\text { 1. The interview questions } \\
\text { are understandable }\end{array}$ & 4 \\
\hline & 2. User is easy to answer & 4 \\
\hline
\end{tabular}




\begin{tabular}{|c|c|c|}
\hline & $\begin{array}{l}\text { the question directly } \\
\text { 3. The estimated time } \\
\text { given to answer the } \\
\text { question is sufficient for } \\
\text { the user } \\
\text { 4. The display of interview } \\
\text { room is attractive for the } \\
\text { user } \\
\text { 5. All interview questions } \\
\text { already cover the needs } \\
\text { of users }\end{array}$ & 4 \\
\hline $\begin{array}{l}\text { Rubric for } \\
\text { Interviewer }\end{array}$ & $\begin{array}{l}\text { 1. The pronunciation used } \\
\text { is clear } \\
\text { 2. The language used is } \\
\text { understandable and } \\
\text { communicative } \\
\text { 3. The intonation of } \\
\text { interviewer is clear }\end{array}$ & 4 \\
\hline \multirow[t]{2}{*}{$\begin{array}{c}\text { Rubric for } \\
\text { Interview } \\
\text { Content }\end{array}$} & $\begin{array}{l}\text { 1. The grammar used in } \\
\text { interview question is } \\
\text { right } \\
\text { 2. The questions in each } \\
\text { session are relevant in } \\
\text { the context of job } \\
\text { interview. } \\
\text { 3. No interview questions } \\
\text { are distorted } \\
\text { 4. The interview questions } \\
\text { are well-ordered }\end{array}$ & 3 \\
\hline & Total & 45 \\
\hline \multicolumn{2}{|c|}{ Validation Score } & $93.75 \%$ \\
\hline
\end{tabular}

Table 3 is The Result of Content Validation of Job Interview on Virtual Reality

The content validation for Job Interview was assessed based on three aspects, namely: (a) content for interviewee (b) content for interviewer, and (c) content for interview questions. According to the validation by the expert, the score of content validation reach $93.75 \%$ which was obtained from the calculation of the score of statements in the rubric.

After the experts validated the application based on their field, the researcher identified the result of the score through their assessments on every single statement in the rubric. The total score showed that the score of the product and the design validation reach $93.33 \%$ and the score of the content validation reach $93.75 \%$. It means that the score of all validation can be categorized as very valid level (based on Akbar, 2013 in 
Table1). Furthermore, the application can directly try to the users/students in order to know the responses about the impact of application for them.

\section{- Trial of User}

As the score classified into very valid category, the application of job interview on Virtual Reality can be implemented to the students directly. The respond from the students as the users for Virtual Reality Application shows that the interview questions provided are easy to understand so that the students have no difficulty in answering some available questions. The students stated that the interview questions provided are in accordance with their learning. It showed that they were able to answer the questions appropriately and directly. They felt comfortable when doing interviews through the Virtual Reality Application. Moreover, the display in job interview application looks right to the students when doing interview.

The students as the users felt motivated and enthusiastic in conducting the interview so that it made them felt more confident to learn interview independently. They could measure their ability to answer questions through the result score and time provided. It could indicate their interview skills through the score after answering the questions. Therefore, after conducting the interview through the application, they knew more about the interview questions so that they can learn to give the best answers. Moreover, they also give recommendation that their answers from the interview questions hopefully can be recorded or even saved to the application so that they can evaluate more toward their answers.

\section{- Product Design}

The design of job interview application appliedinVirtual Reality System was created based on the real-view of interview room and situation. Some features which included interviewer, table, chair, cupboard, and other supporting stuffs designed by the researcher in order to make the atmosphere of interview session looks just like real. The additional menu and scoring provided on the application to give information to the users about the instruction and the result of score that will appear after they answer the questions. There was a time to answer the question for about 30 seconds so that the users are aware of what they are talking about and drive the users to give the best and specific answers. Here are the following displays of the initial product design before it was developed based on the expert validation and the users' response.

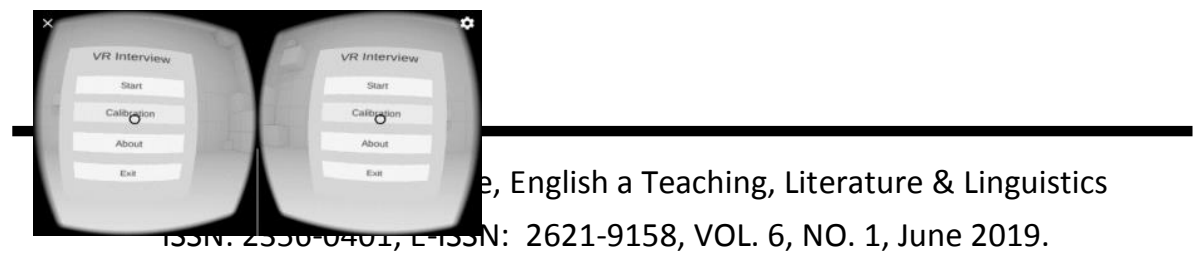


Figure 3. The display of Job Interview Menu

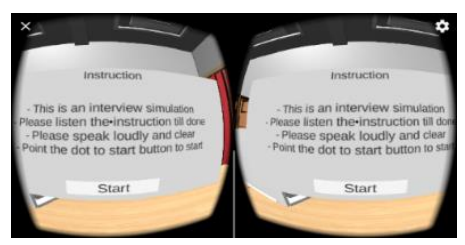

Figure 4. The instruction to use the application

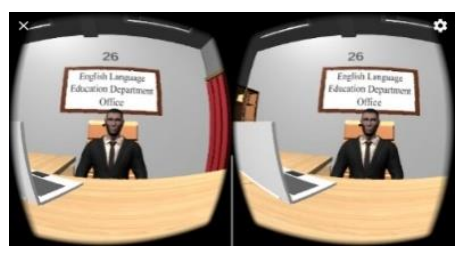

Figure 5. The display of interviewer

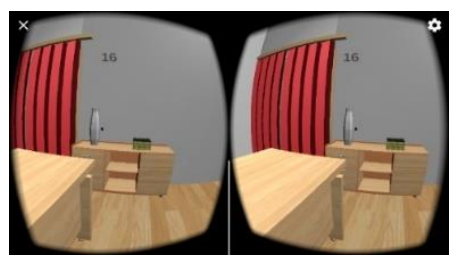

Figure 6. The display of interview room

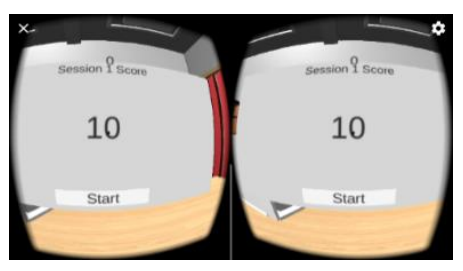

Figure 7. The display of interview score

The design of the product still needs improvement to perform better for the users, especially to educate them. Hence, the researcher also concerns to the suggestions and comments from the experts and users about the development of the design, content, and system to display better. The development consists of features, scoring system, and additional button as follows: 


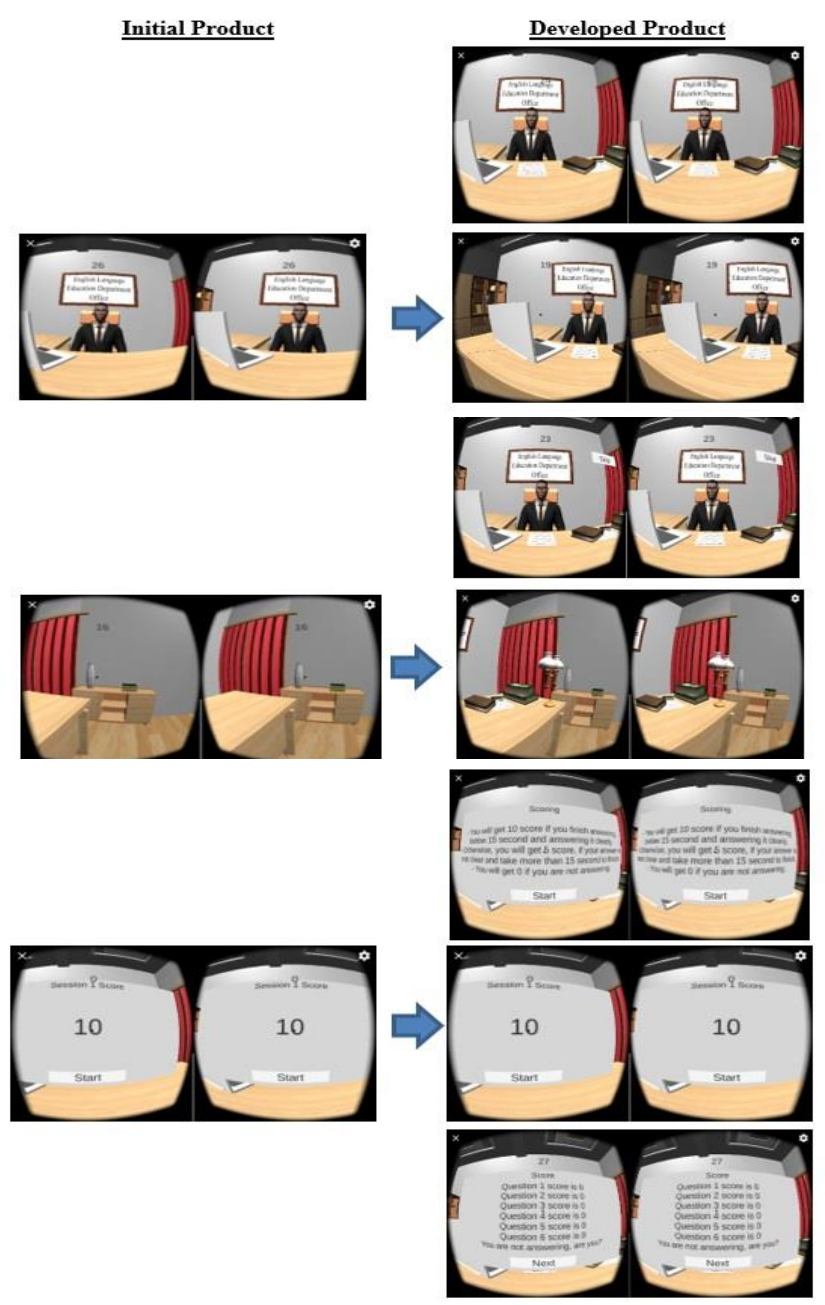

Figure 8. Initial and Developed Products

The features focused on the additional supported stuff such as books, paper, lamps, and flower vase in order to give more interesting situation. The scoring system was made to display in detail result score and instruction how the users will get the score so that the users could evaluate themselves through the result. The additional button was designed to go for the next question so that if the users answered the questions before the limited time given, they could direct the cursor to the "skip" button and get another question. 
The list of the questions applied in the job interview application was based on the suggestion of the Business English lecturer which had been taught to the students by using her experiences to be a job interviewer. The questions were divided into three parts, namely: personality, company knowledge, and working agreement. It will affect the score decision for each part/session in the application. The used questions used for the Job Interview application are listed below.

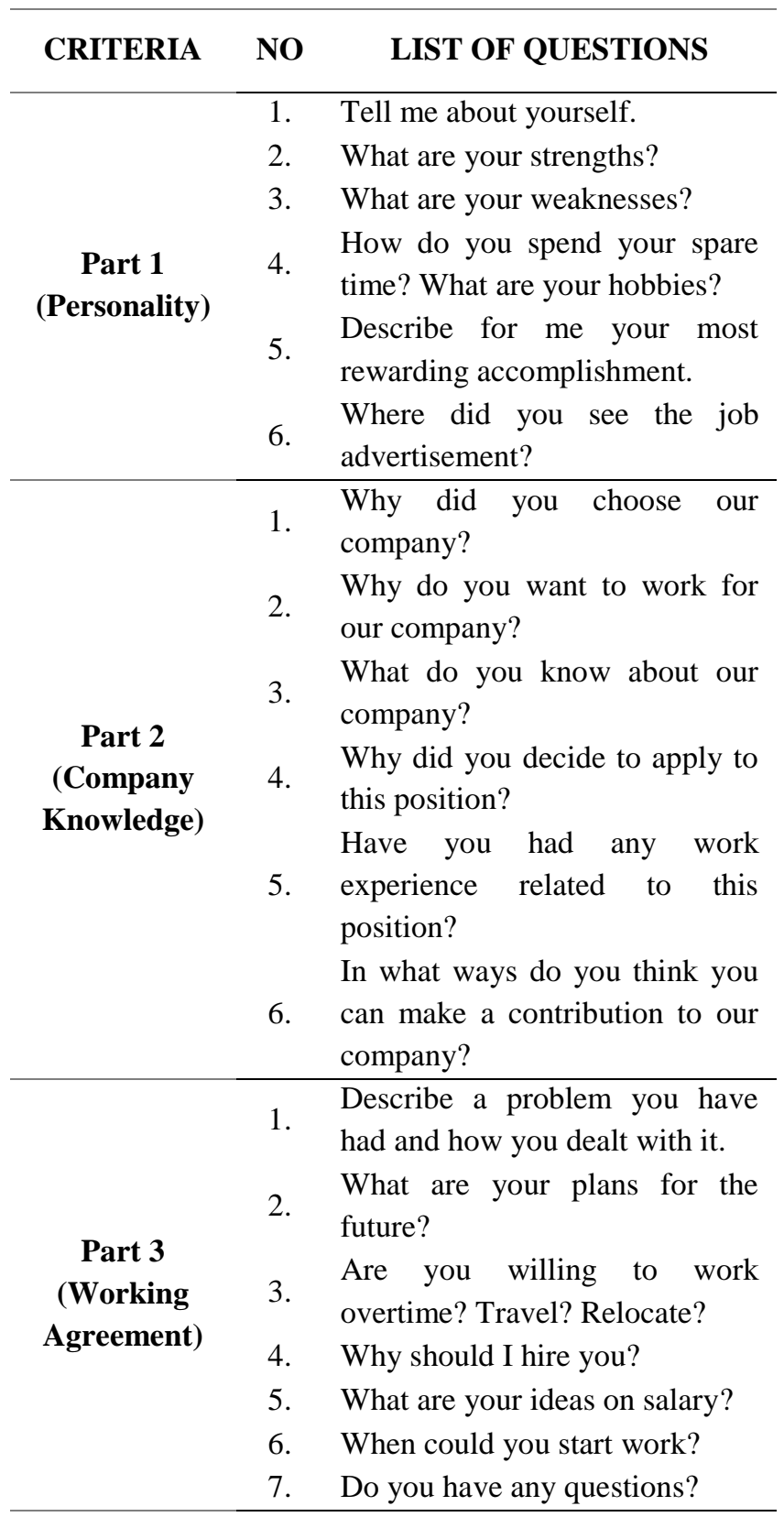

Table 5 is List of Interview Questions 


\section{Discussions}

The result of implementing job interview application through Virtual Reality System is inspected further in discussion. The discussion covers the meaning of the findings which include the result of validation from the expert, the students' reaction on rubric, and the development of the job interview application.

According to the rubric, the product validation has the overall assessment in the score of 4 which means that the application of job interview exceeds expectation or no modification is needed. In the other side, several statements show that this product still has evaluation to meet expectation but could be improved with minor changes with the score of 3 . The expert hopes that the ability of virtual reality to create real context of job interview should be more relevant for the users. This expert's expectation relates with the argument of Held (1993, as cited in Mandal, 2013) which expanded that telepresence happened when the manipulators have the expertise to allow operators to perform normal human functions.

The result of the assessment on the design validation is different from the product validation. Although the overall score is 4 , there are three statements that need minor changes or could be improved to be better. Based on the expert, the arrangement and location of the text and images, the environment presented with the real context, and the environment presented have to be more attractive for and appropriate with the users. It is in line with Desai et al. (2014) who stated that Virtual Reality (VR) gives effect as if the users are in concrete existence as well as 3-Dimensional computer-simulated environment.

The expert of the product and design validation gave comments and suggestions toward the improvement of job interview application. He said that interviewee session in several questions is too long. It will be better if there is a button in directing to the next question. Moreover, it will be more useful if the sound is recorded along with its score. The study about the need analysis in using Virtual Reality for Job Interview simulation that has been done by Jailani (2017)showed that users have expectation that the application can improve to be better and run well.

The overall scores show that the content of the interview is easy to understand and attractive. It can be seen from the score of 4 that the expert gave. On the other side, there are statements with the score of 3 regarding on estimated time given and questions for interview that implies the researcher have to develop it to be better. It is supported by Jailani (2017) who stated that the users felt comfortable to answer the questions because they feel confident, and it can increase the ability of their speaking.

The expert assessed the content for interviewer to be very good. It can be seen from the score of experts given is 4 which means that the pronunciation, language, and intonation made by the researcher are clear and understandable. As Harmer (2001) 
stated that the interaction happens when one or more person doesspeak. Hence, speaking as an effective skill involves a good deal of listening, understanding of feeling, and knowledge about the linguistics terms.

According to the rubric of the validation, the scores of contents for interview questions are generally classified in very well or score of 4 . It means that the interview questions for users are easy to understand regarding on the use of grammar and relevant question with interview context. It supported by Miller et al. (2014)suggest that interviewee should develop a clear intellectual understanding of how to interview effectively and learning to apply these ideas in practicing interviews. That is why the questions is important to be comprehended well in job interview session.

The expert of content validation gave comments and suggestions toward the improvement of job interview application. She said that this kind of product for interview practice can be developed for further research in order to make users always update about their knowledge in interview fields.

Job Interview application that has been said to be feasible and validated from the experts are then tested to the users. It is tested to 10 students from Business English Class. The students try to use Virtual Reality Glasses with the application insides the Glasses. They follow the instructions and choose the menu to point them on Job Interview simulation. Afterward, the students were asked to fill the rubric in order to express their feeling and responses after using the application. In order to make the students feel more comfortable in using the application, the new variety of features are recommended to be added (Jailani, 2017). Therefore, the result of the responses was used for developing the application.

Students gave more attention to the interview questions provided and the usage of application that can create a comfortable situation. The application is very interesting and sophisticated because it can help the students to explore themselves in being interviewee through interview questions provided (Jailani, 2017). The interview questions are easy to understand for the student and suit with the level of interview that have been learned by the student in Business English Class. Miller et al. (2014) has been observed that interviewees should provide their self with the self-analysis questions to have chance in exploring another related interview question. Therefore, the researcher arranges the questions on that way to help the students, at least, they know and enjoy the basic questions of interview. According to the lowest score that reach $10 \%$, some students have different point of view on the statement of related questions with the material and the room is less attractive. According to Gutiérrez et al. (2017), virtual technologies can increase students' engagement and motivation in their teaching and learning activities. Therefore, the lowest percentage responses from the students will be developed features for researcher to make the application performs well. 


\section{CONCLUSIONS}

Based on the finding and discussion, the development of Job Interview application can be done by the validity of the experts and the process of drawing conclusion on the students' response after they tried the application. The validation focused on three major aspects of the application, namely product, design, and content validation. The score of product and design validation reach $93.33 \%$ and the score of content validation reach $93.75 \%$. It can be concluded that the whole scores are very valid category so that the application can be directly tried out to the students of Business English.

The result of students' reaction rubric showed that the students were motivated and attracted to the development of Job Interview application. Hence, the interview questions provided were in line with the material that they learned in the class. They were enthusiastic with the development made by the researcher because it covered the needs of job interview practice rather than the initial product that they ever tried before. The researcher developed Job Interview application based on three major aspects that concerned to the suggestions from the experts and students.

Job Interview application is developed based on features, scoring system, and additional button. The features include the interior design and some supported stuffs such as flower vase, paper, books, and lamps. The scoring system developed to the detail information on how the students/users will get the score and the display of the score for each session. Furthermore, the additional button is added in order to make the users feel easy to try another interview question when the limited time to answer the question is not over. The interview questions were divided into three main parts, namely personality, company knowledge, and working agreement. Each part consists of 6 to 7 questions for the users to answer.

\section{REFERENCES}

Abulrub, A. G., Attridge, A., \& Williams, M. A. (2011). Virtual Reality in Engineering Education: The Future of Creative Learning. Amman, Jordan: Princess Sumaya University for Technology. https://doi.org/http://dx.doi.org/10.3991/ijet.v6i4.1766

Akbar, Sa'dun. (2013). Instrumen Perangkat Pembelajaran. PT Remajar Rodakarya Bandung.

Bereczky, K., \& Gabor, D. (2009). The Identity of the Business English Teacher: A Pilot Study, 83-98.

Burnley, S. (2017). The use of virtual reality technology in teaching environmental engineering The use of virtual reality technology in teaching environmental engineering. A Journal of the Higher Education Academy ISSN:, 0052(December), 1-15. https://doi.org/https://doi.org/10.11120/ened.2007.02020002

Chaudhury, S. (2014). Virtual reality applications in mental health: Challenges and perspectives, (July), 2014-2017. https://doi.org/10.4103/0972-6748.151666 
Clark, T. (2014). How Palmer Luckey Created Oculus Rift | Smithsonian.

Clayton, K., \& Murphy, A. (2016). Smartphone Use as Tool for Learning, 8, 99-109.

Desai, P. R., Desai, P. N., Ajmera, K. D., \& Mehta, K. (2014). A Review Paper on Oculus Rift. International Journal of Engineering Trends and Technology (IJETT), 13(4), 175-179. https://doi.org/10.14445/22315381/IJETT-V13P237

Guide, A. Q. (2011). Job Interviews, 1-9.

Gutiérrez, J. M., Mora, C. E., Diaz, B. A., \& Marrero, A. G. (2017). Virtual Technologies Trends in Education. EURASIA Journal of Mathematics Science and Technology Education, 8223(2), 469-486. https://doi.org/10.12973/eurasia.2017.00626a

Harmer, J. (2001). The Practice of English Language Teaching (Third Edit). Cambridge, UK: Longman.

Jailani, M. K. (2017). Needs Analysis on Virtual Reality System Using VR Glasses i n " Job Interview " of Speaking Activity. In NEEDS ANALYSIS ON VIRTUAL REALITY SYSTEM USING VR GLASSES IN “JOB INTERVIEW” OF SPEAKING $A C T I V I T Y$. Malang, Indonesia: State University of Malang.

Kew-Cheol Shim, Jong-Seok Park, Hyun-Sup Kim, Jae-Hyun Kim, Y.-C. P. \& H.-I. R. (2010). Application of virtual reality technology in biology education_ Journal of Biological Education_ Vol $37, \quad$ No 2. https://doi.org/https://doi.org/10.1080/00219266.2003.9655854

Kučírková, L., Vogeltanzová, T., \& Jarkovská, M. (2011). BUSINESS ENGLISH COURSES ONLINE SUPPORT, 4(4), 197-206.

Ma, R., \& Kaber, D. B. (2006). Presence, workload and performance effects of synthetic environment design factors. International Journal of Human-Computer Studies, 64, 541-552. https://doi.org/10.1016/j.ijhcs.2005.12.003

Mandal, S. (2013). Brief Introduction of Virtual Reality \& its Challenges, 4(4), 304309.

Miller, D., Catt, S., \& Slocombe, T. (2014). Job Interviews: Keys for Results. Administrative Issues Journal Education Practice and Research, 4(2), 77-82. https://doi.org/10.5929/2014.4.2.5

Motteram, G. (2013). Innovations in learning technologies for English language teaching. (G. Motteram, Ed.). London, UK: British Council.

Novitasari, D. L. (2016). Pengembangan media komik cerita anak untuk meningkatkan keterampilan menulis narasi siswa kelas iv sdn 1 ngawen kabupaten blora. Universitas Negeri Semarang.

Psotka, J. (2013). Educational Games and Virtual Reality as Disruptive Technologies, $16,69-80$.

Rambitan, V. M. M. (2015). The Effect of Smartphone on Students ' Critical Thinking Skill in Relation to the Concept of Biodiversity, 3(2), 243-249. https://doi.org/10.12691/education-3-2-18 
Sugiyono. 2011. Metode Penelitian Kuantitatif, Kualitatif, dan R\&D. Alfabeta, Bangung

Sukmadinata, Nana Syaodih. 2016. Metode Penelitian Pendidikan. PT Remaja Rosdakarya - Bandung.

Walisongo, E. (1983). Gall, M, D., Gall, J. P., \& Borg, W. R. Educational Research an Introduction; Third Edition, 24-34.

Wilson, C. J., Soranzo, A., \& Sheffield, S. (2015). The Use of Virtual Reality in Psychology: A Case Study in Visual Perception, 2015. https://doi.org/10.1155/2015/151702

\section{ACKNOWLEDGEMENT}

The gratitude is directed to English Language Education Department and Informatics Lab of University of Muhammadiyah Malang for supporting this study. 